\title{
Den livsoplysende tekst
}

\author{
Af K.E. Bugge
}

Fredag d. 30. januar 1998 forsvaredes en Grundtvig-disputats ved Linköpings Universitet i Sverige. Forfatteren er Bosse Bergstedt, der er ansat $i$ en forskerstilling ved dette universitets Institut for Padagogik og Psykologi. Afhandlingen, der er på 368 sider, barer titlen "Den livsupplysande texten. En läsning av N.F.S. Grundtvigs pedagogiska skrifter« (Carlsson Bokförlag, Stockholm 1998).

Bosse Bergstedts (herefter forkortet: BB) afhandling påkalder sig interesse allerede derved, at den er den fjerde i rækken af svenske Grundtvig-disputatser. Tidligere udkom Sven Bergentz: N.F.S.Grundtvigs religiösa idealism (Lund 1923), - Harry Aronson: Mänskligt och kristet. En studie i Grundtvigs teologi (Stockholm 1960), og - Tord Ehnevid: Församlingsetik. Studier över Grundtvig, Morten Pontoppidan och Einar Billing (Lund 1969).

Men også af andre grunde er BBs afhandling et interessant arbejde. Først og fremmest må nævnes, at $\mathrm{BB}$ behandler et overordentlig centralt tema i Grundtvigs forfatterskab: Forholdet mellem mundtlighed og skriftlighed. Endvidere er i arbejdet inddraget nyere sprogfilosofi og litteraturteori. Sidst, men ikke mindst er afhandlingen interessant, fordi den gennemfører en sproglig og litterar analyse af Grundtvigs pædagogiske forfatterskab frem for at rette søgelyset mod disse teksters idéer. På den måde repræsenterer afhandlingen en ny tilgang til studiet af Grundtvigs skoletanker.

I det følgende skal først meddeles en oversigt over afhandlingens indhold. Derefter skal knyttes nogle supplerende og kritiske bemærkninger til udvalgte enkeltheder og afsnit $i$ bogen. At der rundes af med konkluderende overvejelser, vil næppe overraske nogen! Men nu først bogens indhold:

Efter et Forord med de obligate taksigelser og en kort »ingång «, hvor BB beskriver sit møde med København, Det Kongelige Bibliotek og Grundtvigs skrifter, følger bogens hovedtekst opdelt i seks kapitler. Det første kapitel, der er overskrevet »Före kunskapen «, gør rede for afhandlingens forudsætninger og grundlæggende idéer. Under sit arbejde med Grundtvigs tanker om livsoplysning er BB blevet fascineret af den iagttagelse: At selv om Grundtvig gang på 
gang fremhæver, at det skrevne ord er dødt, og at kun det talte ord er levende, så har han ikke desto mindre ved hjælp af et særdeles omfattende skriftligt; trykt forfatterskab tilstræbt at overbevise sine samtidige om denne sandhed. Når det - trods Grundtvigs principielle opfattelse af forskellen mellem døde bogstaver og levende ord alligevel er ham om at gøre at meddele sig skriftligt om denne forskel, skyldes det ifølge BB,

- at Grundtvig synes at regne med den mulighed, at synlig tekst og skrift indirekte kan pege på og udtale sig om åndens usynlige virkelighed,

- at sproget ikke er »ett enhetligt fenomen«, men at det indeholder et spil af modsatninger (svensk: et "spel av skillnader«); der er m.a.o. en vekselvirkning $i$ sproget, der giver sig udtryk bl.a. i gåder, paradokser, metaforer m.m.

- at der i læserens møde med teksten netop på grund af dette "spil« frigøres en åndelig kraft, der medvirker til menneskelig forandring. På den måde kan en tekst, idet den peger ud over sig selv, blive livsoplysende i Grundtvigs forstand.

I et følgende underafsnit redegøres først for Grundtvig-receptionen i Sverige og for fremvæksten af folkehøjskoler i Norden og rundt omkring i verden. Dernæst fokuseres på den Grundtvig-forskning, der har haft særlig betydning for BBs studier. BB har i så henseende valgt primært at interessere sig for den forskning, der er fremkommet i tiden efter 1945 . Vi skal senere vende tilbage til denne forskningsoversigt.

Efter en udførlig omtale af sine inspirationskilder i nutiden vender BB tilbage til beskrivelsen af sit arbejde med Grundtvigs tekster. Han indrømmer oprigtigt, at han har været meget usikker mht., hvorledes han skulle gå frem. Han nåede efterhånden frem til, at det måtte være vigtigt at opøve sin egen opmaerksomhed dvs. at interessere sig for de ofte oversete detaljer, fx det tilsyneladende perifere i teksten, de forekommende tillæg og metaforiske understrømme og endelig »rösten«, dvs. tekstens stemmeføring. Herunder opdagede BB, at det fremmer forståelsen, at man læser teksten højt. En sådan højtlæsning kan bidrage til at indfange spillet af modsætninger.

I et følgende afsnit omtales »To strategier«, som Grundtvig tilsyneladende har anvendt, og som BB i hvert fald har fundet det givende at rette opmærksomheden imod: 
(1) »omvändningen « dvs. omvendingen, inversionen, Eng. Reversal.

(2) »förskjutningen«, dvs. forskydningen, Eng. Dislocation.

Betydningen af disse vigtige begreber bliver derpå uddybet:

$\mathrm{AD}$ 1: Grundtvig opererer med tre modsætninger, der ikke kan vekselvirke med hinanden: Liv-død, lys-mørke, sandhed og løgn.

Disse kontradiktoriske modsætninger er i kamp med hinanden lige til verdens ende. I dette grundlæggende perspektiv må man forstå, at Grundtvig i sine pædagogiske skrifter vender om på den vesterlandske kulturtraditions efter hans opfattelse $\mathrm{i}$ bund og grund forkerte prioritering: At man sætter døden over/forud for livet. Grundtvig »omvender « (inverterer) den traditionelle vurdering, og denne »omvending « skaber en åbning $i$ sproget: Livet må nødvendigvis demonstrere, hvorledes det adskiller sig fra døden. Hvilke våben kan livet benytte $\mathrm{i}$ denne kamp ? Kunne det være en satsning på modsætninger, der kan vekselvirke, og som således skaber nye meningshelheder?

AD 2: Det næste skridt er at fokusere på de retoriske indslag i de tekster, der viser hen til livsoplysningens mulighed. Dermed sættes tekstens modsætninger i bevægelse, så at de siger noget, der ellers ikke kan siges. På indirekte måde skrives nogle spor af en åndelig kraft.

Afsluttende skitseres indholdet af bogens seks kapitler. Kapitel 1 gør rede for forfatterens forudsætninger og anliggender. Kapitlerne 23-4-5 følger »en biografisk linie« gennem Grundtvigs liv, idet BB her gennemgår en række Grundtvig-tekster i kronologisk rækkefølge, fra Danne-Virke-tiden (1816-19) frem til Marielysttalerne fra 1856-71. Kapitel 6 sammenfatter og diskuterer de erkendelser, som forfatteren er nået frem til, og en kort »utgång « beskriver arbejdets afslutning.

Bogens andet kapitel bærer overskriften »En vandring $i$ människans bild «, dvs. en vandring i menneskeopfattelsen. BB retter her opmærksomheden mod DV-afhandlingen »Om Mennesket $i$ Verden « (DV II, 1817). Afhandlingen er den første af de Grundtvig-tekster, som BB agter at gennemgå med henblik på at dokumentere sin tese om den livsoplysende tekst.

Efter tre indledende biografiske underafsnit, som vi siden skal vende tilbage til, følger den resterende - og langt udførligste - del af 
kapitlet. Her følger BB (og læseren) Grundtvig på hans »Vandring ind i Menneske-Lundens Irgange « (DV II, 140). BBs gennemgang af »Om Mennesket i Verden« prætenderer ikke at referere alt, hvad Grundtvig her skriver. Hovedsagen har for ham været at gøre rede for Grundtvigs koncentrerede og indholdsrige tankeudvikling, hvilket også må siges at være lykkedes. Af større betydning er imidlertid de afsnit, BB har fremdraget med henblik på at underbygge sin tese. I den sammenhæng vækker BBs fremdragelse af en række »Mellemspil« umiddelbart interesse.

Det drejer sig om indskud, hvor Grundtvig forlader den objektivt fremsættende stil og slår over i direkte - og undertiden småsnakkende - tiltale til og drøftelser med læseren. Sammenfattende kan siges, at disse mellemspil bekræfter BBs opfattelse: At der i denne afhandling findes eksempler på retorisk »forskydning «.

I tredie kapitel gennemgår BB Indledningen til Nordens Mythologi (1832). Kapitel-overskriften »Silverbröllopet « hentyder til, at Grundtvig i fortalen indbyder til et sølvbryllup i anledning af, at det i 1832 er 25 år siden, at han forelskede sig i den nordiske mytologi.

Også her indleder BB med at opridse en biografisk horisont, der dog denne gang alene omfatter et enkelt underafsnit. På de følgende ca. 30 sider har BB leveret en solid og velkomponeret gennemgang af denne berømte indledning. Efter hans opfattelse illustrerer teksten den tidligere omtalte »omvändning «, idet Grundtvig først udførligt beskriver og karakteriserer den døde videnskabelighed, han bekæmper. Derpå sker ifølge BB det, at teksten »vänder« eller »byter fot « og i det følgende beskriver den folkelige »Vidskab eller Folke-Dannelse og Folke-Oplysning i rigtig aandelig Forstand«, som Grundtvig $\emptyset$ nsker at fremme.

Opmærksomheden rettes derefter mod tekstens retoriske strategier, af hvilke BB bl.a. ved hjælp af en række citater omtaler tretallet, lignelser og metaforer, udråb og tiltale til læseren (sml. kap. 2) samt ironi. BB har herunder bl.a. fæstnet sig ved, at sølvbryllups-indbydelsen til at beskæftige sig med »døde« myter blev et møde med meget levende ord! BB slutter kapitlet med at fastslå, at billedet af de retoriske »strategier«, Grundtvig anvender, i væsentlig grad afklares $\mathrm{i}$ dette værk fra 1832.

I kapitel 4 indbyder BB til en rejse, der skal føre læseren til »Två skolor för livet« beliggende henholdsvis i Sorø og Göteborg. 
Med det formål rettes opmærksomheden mod Grundtvigs klassiske højskoleskrifter og herunder især »Skolen for Livet« (1838) og »Om Nordens videnskabelige Forening « (1839). Endvidere inddrages enkelte af de mindre kendte blandt de pædagogiske skrifter, og for første gang inddrages digte. Som det fremgår, drejer det sig for størstedelens vedkommende om de skrifter, der er trykt i bd. 2 af Grundtvigs skoleverden i tekster og udkast (1968). Derudover forekommer enkelte citater fra Grundtvigs »Mands Minde«-foredrag (1838, trykt 1877) og fra »Statsmæssig Oplysning« (1834, trykt 1983).

Det indledende biografiske afsnit, der med sine ca. to sider er kortere end de forudgående tilsvarende indledninger, omhandler perioden fra midten af 1830 'erne til midten af 1850 'erne. I den efterfølgende behandling af teksternes indhold er stoffet ordnet tematisk. Det vil sige, at $\mathrm{BB}$ frem for at gå kronologisk frem har valgt at opbygge sin fremstilling omkring en række centrale begreber og synspunkter.

I denne kompetente og velskrevne fremstilling bemærkes især de mange gode eksempler på det træk, $\mathrm{BB}$ har kaldt »omvändningen «. I de efterfølgende eksempler på de retoriske strategier, BB har kaldt »förskjutningar « $\mathrm{i}$ teksten, omtales Grundtvigs anvendelse af ordsprog og udråbstegn. Ud over den tidligere omtalte dialog med laeseren drøftes som noget nyt $\mathrm{i}$ forhold til fremstillingen i de tidligere kapitler Grundtvigs brug af bindestreger, hvormed han skaber nye ord og muliggør betydnings-forskydninger. Endvidere omtales Grundtvigs »kursiveringer «. Strengt taget er dette en misvisende terminologi. Det er ikke kursiveringer, men først og fremmest spatieringer, der er karakteristiske for Grundtvigs trykte prosa.

Indholdet af bogens femte og korteste kapitel signaleres med et enkelt ord: »Marielyst «. Efter en biografisk indledning på ca. en side bringes i kapitlets første afsnit en række eksempler på og kommentarer til tekstens »omvändningar«. Derpå følger nogle eksempler på andre retoriske strategier, fx udråbet »Nu da! « tiltaleformen »See !«, det mytiske billedsprog og folkelige ordsprog.

Afsluttende fremlægges den iagttagelse: At der synes at være meget lidt forskel mellem sproget i Grundtvigs tale-manuskripter på den ene side, og på den anden side de tekster, der blev skrevet med henblik på at blive trykt. 
Det sjette og sidste kapitel bærer overskriften »Livsupplysning«. Her uddyber BB nogle af de iagttagelser, han har gjort under det forudgående arbejde med Grundtvigs pædagogiske tekster. Endvidere tages en række andre relevante og centrale temaer op til behandling. Den tematiske fremstillingsform kaldes her med et upretentiøst udtryk for »en collage «.

Med udgangspunkt i Ove Korsgaards store værk om folkeoplysningens idéhistorie, "Kampen om lyset « (København 1997), drøftes først nogle grundtyper på forståelse af denne særlige undervisningsopgave. Som det var at forudse, er det umuligt at indplacere Grundtvig entydigt under en enkelt af de anvendte kategorier. Grundtvig omtolker den europæiske dannelsestradition og tilføjer den et nyt, originalt udtryk.

Det følgende afsnit bringer bl.a. en opsummerende fortegnelse over de iagttagne »omvändningar « af modsætninger samt af de andre retoriske indslag i teksterne. Om disse »spel med skillnaden« bemærkes, at der trods alle analytiske bestræbelser forbliver noget usynligt og gådefuldt i teksten. Heri ligger efter BBs opfattelse en vigtig pædagogisk pointe: At den rette vej til kundskab indebærer, at man ikke tilstræber at gøre alt »sägbart « (s. 240). Med henblik på forståelse af den kundskabsproces, Grundtvig tænker på, drøftes derpå en række enkeltheder $i$ teksterne som $f x$ henvisningen til den folkelige sang samt til kvinden og kærligheden.

Et tredie afsnit drøfter Grundtvigs forhold til romantikken. BB refererer hovedstadierne af den omfattende forskning inden for dette emneområde. En af forskningens vanskeligheder har været, at det er næsten umuligt at finde en enkelt tilfredsstillende definition af begrebet »romantik«. BB har imidlertid ret $\mathrm{i}$, at et centralt punkt $\mathrm{i}$ drøftelsen må være forholdet mellem den romantiske enhedsfilosofi på den ene side og de modsigelsesforhold, der fundamentalt præger Grundtvigs tænkning, på den anden side.

Det fjerde afsnit drøfter Grundtvigs astetik og poetik. I den forbindelse citerer BB en karakteristisk udtalelse fra DV III (1817), der beskriver den poetiske inspiration, et emne, der unægtelig er centralt i Grundtvigs forfatterskab. På afsnittets sidste sider bringes nogle fine formuleringer, hvor BB præciserer, hvad en livsoplysende tekst kan og ikke kan: 
"Den som frigör ljus i mötet med texten är den som läser. Texten kan inte i sig själv uttrytcka den andliga kraften, det är läsaren som i mötet med texten kan få ljuset att lysa« (s. 256)

Texten bliver i sig själv en metafor för vad som menas med livsupplysning, den både pekar på nödvändigheten av en levande växelverkan och visar själv hur denna kan omsättas i praktiken.

På så sätt kan texten generera en kraft, om den läses på rätt sätt. Den livsupplysande texten behöver därför en läsare, som söker livsupplysning« (s. 257).

Det femte afsnit drøfter forholdet mellem Grundtvigs tanker om folkeoplysning på den ene side, og det dannelses-begreb, der i vore dage oplever en renæssance, på den anden side. Med rette understreges, at ihvorvel man kan få øje på visse paralleller mellem dannelse og livsoplysning, er der dog grundlæggende tale om »två skilda kunskapsprojekt « (s. 262). Det er især Grundtvigs fremhævelse af Åndens gerning, der sætter skel mellem de to begreber. Dertil kommer, at dannelsestænkningen rummer en risiko for menneskelig selvovervurdering, at »människan gör sig själv til Gud i sin tro på att kunna behärska en motsägelsefull värld« (s. 264).

Sjette afsnit er overskrevet »Livsupplysning och postmodernism《. BB har fundet postmoderne indslag i Grundtvigs tankeverden, især i hans tale om vekselvirkning. Grundtvigs historisk forankrede tænkning rummer imidlertid ifølge $\mathrm{BB}$ en kollektiv dimension, der væsentligt adskiller hans tankegang fra postmodernismens stræben efter individuel grænseoverskridelse.

Det afsluttende element i »collagen « er et afsnit, hvor opmærksomheden rettes imod begrebet "mфde". Med Grundtvig har BB oplevet et møde $\mathrm{i}$ den forstand, at de begge i deres optagethed af livsoplysning kan siges at skrive på samme lange tekst. For BBs eget vedkommende har arbejdet med Grundtvig bidraget til hans selvforståelse. Ikke desto mindre har mødet med Grundtvig været karakteriseret af en uovervindelig distance, og hans tekster har bevaret deres gådefuldhed.

Efter denne redegørelse for afhandlingens indhold skal - som bebudet - fremføres nogle supplerende og kritiske bemærkninger. 
Selve tekstudvalget kan ved første øjekast give anledning til overvejelser. Den første tekst fra 1817 er ikke af pædagogisk, men af filosofisk art. Endvidere skulle man synes, at der måtte være forskel på de skoleskrifter, hvor Grundtvig skriver om livsoplysning, og de manuskripter til taler, hvor han direkte meddeler en sådan oplysning. BB har imidlertid foregrebet disse indvendinger. Han er helt klar over de nævnte forskelle. Alligevel har han skønnet under iagttagelse af visse forbehold at kunne forsvare sit tekstvalg. Fremdeles er han (jf. afslutningen af kap. 5) efter nøje overvejelser kommet til det resultat, at selv om visse forskelle mht. sprog og stil kan iagttages mellem de indirekte og direkte oplysende tekster, er disse forskelle dog minimale. På denne baggrund vil man ikke med rimelighed kunne kritisere BBs valg af paedagogiske tekster.

Når dette er sagt, kan man alligevel spørge, om det ikke havde været til BBs fordel at arbejde på et noget bredere tekstgrundlag. Det er en tanke, der melder sig, når man konstaterer, at store områder inden for Grundtvigs forfatterskab enten helt eller næsten helt lades ude af betragtning:

- Teologien. I litteraturlisten anføres to kirkehistoriske værker, dels det store poetisk-visionære digt »Christenhedens Syvstjerne«, dels de trykte kirkehistoriske foredrag »Kirke-Speil« samt det kristelige dramatiske digt »Paaske-Lilien«. Endvidere anføres »Grundtvigs prædikener« i Thodbergs udgave, bd. 1-12, (Kbh. 1983-1986) dog ikke de 2 bind Præst $\varnothing$-prædikener (Kbh. 1988). Imidlertid synes ingen teologiske skrifter, digte eller prædikener at være inddraget $\mathrm{i}$ fremstillingen.

- Filologi og historieskrivning er kun lige nævnt.

- Digtning. Af verdslige digte er kun citeret de skolesange, der er optaget i »Grundtvigs skoleverden« etc. bd. II (Kbh. 1968), og af salmer tilsyneladende ingen. Dette er ejendommeligt, eftersom Grundtvig netop i poetisk form ofte udtrykker sig klarest.

- Taler og foredrag. Et helt kapitel (Kap. 5) behandler Marielysttalerne, og enkelte citater bringes fra Grundtvigs »Mands Minde«foredrag. Andre taler og foredrag inddrages ikke, fx Grundtvigs landemodetaler fra 1811-14, de mytologiske og historiske foredrag 
samt talerne i Danske Samfund 1839 og fremefter, hans taler ved forskellige offentlige lejligheder, og - sidst men ikke mindst - Grundtvigs talrige Rigsdagstaler. Denne afgrænsning er overraskende, al den stund at BBs centrale problemstilling netop er forholdet mellem skriftlighed og mundtlighed.

- Breve. Af interesse i BBs sammenhæng er især Grundtvig-Ingemann-brevvekslingen; denne er nævnt i note 627, men ikke i litteraturlisten. Men netop i denne brevveksling findes en udførlig drøftelse af temaet skriftlighed-mundtlighed. Og her finder man den berømte udtalelse om den mundtlige meddelelses primat:

»...det eneste under Solen, hvori denne højere (dvs. åndelige) Betragtning af Verden og Livet kan levende udtrykke, forplante og meddele sig, er det mundtlige, lydelige Ord. Dette paastaar jeg nu dels som en Erfarings-Sandhed og dels som en Naturlov, saa det er mig umuligt at tænke anderledes...Ordet paa vore Læber er det eneste usynlige, som med Liv kan udtrykke Tanker og Følelser, altsaa det eneste levende og sandselige paa Jorden, hvori den usynlige Aand selv kan være, hvoraf synes nødvendig at følge, at det lydelige Ord ogsaa er det eneste, hvorigjennem Aand kan virke levende.« (»Grundtvig og Ingemann. Brevvexling «, Kbh. 1882, s. 194-195; Grundtvig til Ingemann 12/1-1837).

Sammenfattende kan siges, at BB ved at udgrænse de nævnte områder har afskåret sig fra et stort materiale, der kunne belyse hans tese.

Hvad angår tekstbenyttelsen, er det i første omgang af særlig interesse at få fastslået, i hvilket omfang $\mathrm{BB}$ har anvendt håndskrifter fra Grundtvig-arkivet. Af litteraturlisten s. 340 (under f, Fasc.= fascikel) ses, at $\mathrm{BB}$ har benyttet $\mathrm{i}$ hvert fald ét håndskrift. Også af bogens »ingång « (s. 13) synes at fremgå, at håndskrifter er benyttet.

Imidlertid forholder det sig således, at BB kun et enkelt sted (s. 237-238) gør direkte brug af utrykt materiale. S. 237 omtaler BB en hidtil upubliceret tekst. Af noterne 587a og 588 fremgår, at der er tale ikke om ét, men om to forskellige manuskripter: Fasciklerne 154.28 og 182.11.- Grundtvig Registrantens bd. VII og VIII daterer disse henholdsvis noget senere end 1860 og 1861 . BB daterer sam- 
menfattende: 1860-65. - Citatet s. $238 \varnothing$ verst er tilsyneladende hentet fra Gr.Reg. VII (1958), regesten til fasc. 154.28 s.II. Altså må konkluderes, at selv om BB faktisk har benyttet Grundtvig-arkivet, er der $i$ bogen ingen direkte citater fra manuskripter.

Som flere gange nævnt i gennemgangen af bogens indhold er BBs redegørelser for Grundtvigs tanker i enkelte tekster og i tekstgrupper pålidelig og oplysende. Denne generelle vurdering gælder - også selv om enkelte fejl kan konstateres i bogens saglige indhold. Eksempelvis må understreges, at det ikke var Christian Kold (!), men Christian Flor, der skabte udtrykket »Folkehøjskole« (Noterne 380 og 512). Og på s. 122 møder man en fejltolkning af et afsnit af Indledningen til »Nordens Mythologi« (1832). Det er ikke Grundtvig, men naturalisterne, der mener, at man skal optage Kristus i sig som et guddommeligt forbillede.

Netop på baggrund af bogens generelle pålidelighed i saglig henseende kan man ærgre sig over, at fremstillingen skæmmes af ikke så få formelle småfejl. Af sådanne må nævnes et ret stort antal fejl i gengivelsen af citater fra dansk. Endvidere er noteret nogle forkerte årstalsangivelser. Endelig forekommer i litteraturlisten en del stavefejl i forfatternavne.

På grænsen mellem formelle og saglige småfejl finder man et ret betydeligt antal unøjagtigheder i de biografiske indledninger. Fra den udførligste af disse, nemlig de indledende underafsnit af Kapitel 2, kan nævnes følgende:

Grundtvigs søster hed ikke »Rilke« (s. 70) - som en velkendt østrigsk forfatter og digter - men »Rikke«, en forkortelse af Ulrica eller Ulrikke.- Hun fødtes ikke, som her oplyst, efter Grundtvig, men året før, i 1782 .

I to billedtekster (s. 71 og 77) hedder det, at henholdsvis Udby præstegård og Valkendorfs Kollegium er set »från havet«. Der skal stå: »från trädgården«, på dansk: fra haven. - Også billedteksten på s. 75 er upræcis. Billedet af Egeløkke er ikke (som forøvrigt også hævdet af Holt \& Madsen: Minderige Steder etc. (1955) s. 71) malet af C. Fabritius de Tengnagel (1731-1805, se DBL bd. 4), der var købmand, men af Frederik Michael Ernst Fabritius de Tengnagel (1781-1849), jf. F. Rønning: Hundrede Aar. Et Mindeskrift i Anledning af Hundredeaarsdagen for Nic. Fred. Sev. Grundtvigs Fødsel (Kbh. 1883) s. 6 
og Weilbachs Kunstnerleksikon I (Kbh. 1947) s. 304-305. Hos Weilbach omtales, at Frederik Michael Ernst bl.a. var kendt for landskabsbilleder fra Langeland. Hans mor var for øvrigt født Leth, sml. fru Constance.

Vedrørende tidens skolereformer meddeles (s. 72), at en skolekommission nedsattes i 1814. Der må være tale om den såkaldte store skolekommission, "Kommissionen for de Danske Skolers bedre Indretning «, der nedsattes i 1789 . Kommissionen kaldtes "stor «, fordi den sad så længe - hele 25 år! Resultatet af kommissionens arbejde var de skelsættende skolelove af 1814, hvor almindelig skolepligt indførtes i Danmark. Kildesamling med indledning og registre er udgivet af Joakim Larsen: Skolelovene af 1814 og deres Tilblivelse aktmæssig fremstillet (Kbh. 1914).

Vedrørende dette afsnit (s. 71-72) henvises i note 145 til Edvard Lehmann: Grundtvig och det danska fromhetslivet (Sthlm 1927) s. 17-19, der her gengives næsten ordret. BB har ikke været klar over, at Lehmanns force ikke just var historisk nøjagtighed.

I det efterfølgende afsnit fører BBs afhængighed af Lehmann til den udtalelse: At Grundtvigs skolegang $i$ Århus hos ham grundlagde en kritisk holdning over for latinskolen, som han siden benævnte »den sorte skole«. BB kunne have bemærket, at både Hal Koch og Pontoppidan Thyssen, hvis biografiske redegørelser han i $\emptyset v r i g t$ støtter sig til, tager afstand fra en sådan opfattelse. Af samtidige kilder fra 1800-1802 fremgår, at Grundtvig befandt sig aldeles udmærket i Århus. Han tilegnede sig solide kundskaber især i historie og latin. Og hans lærere værdsatte hans »ingenium« og ventede sig meget af ham.

På s. 77 hentydes indirekte til digtet »Strandbakken ved Egel $\phi$ $k e$ «, der kaldes »en dikt från Langelandstiden«. Digtets genesis er ret kompliceret. Kun visse dele af det blev skrevet i 1807, og hele digtet blev færdiggjort i 1811 - altså efter Grundtvigs krise i 1810.

Vedrørende Grundtvigs dimispradiken i foråret 1810 omtaler BB et brev fra Grundtvigs far, Johan Grundtvig, hvori denne opfordrer sønnen til at lade sig ordinere med henblik på at komme til Udby som faderens kapellan (hjælpepræst). BB oplyser i den forbindelse, at Grundtvig 12 dage senere holder sin dimisprædiken. Da prædikenen holdtes d. 17. marts 1810 (Begtrup US II, s. 5; Rønning II,1 s. 167), må der imidlertid være tale om Grundtvigs brev af 5/3-1810 til faderen (Breve I, s. 21-22), altså IKKE et brev fra faderen til Grundt- 
vig. - Johan Grundtvigs brev, der satte hele processen i gang, er ikke bevaret. Det må være skrevet »omkring 1. marts« (Rønning II,2 s. 162).

På s. 79 hedder det, at Grundtvig fik afslag på alle embedsans $\varnothing$ gninger, han indsendte i årene 1813-30. Der henvises til Pontoppidan Thyssen s. 11, hvor der står 1813-20. Det ser mere sandsynligt ud.

En væsentlig årsag til denne usikkerhed mht. det biografiske synes at være BBs afhængighed af Edvard Lehmanns Grundtvig-bog fra 1927. Efterhånden som de biografiske afsnit bliver kortere, og desuden afhængigheden af Lehmann aftager, tiltager sikkerheden i fremstillingen. De passager, hvor BB bygger på Pontoppidan Thyssens velfunderede biografiske redegørelse $\mathrm{i}$ jubilæumsbogen fra 1983, er afgjort de bedste.

Hvad angår BBs behandling af den tidligere Grundtvig-forskning, kommer først den allerede nævnte oversigt i kapitel 2 ind i billedet. Her tilstræber BB at typebestemme forskningens vigtigste udgivelser under 3-4 kategorier: (1) Historisk-komparativ, (2) strukturel, (3) biografisk-eksistentialistisk. En fjerde kategori, der kaldes »Nutidig forskning «, er hovedsagelig repræsenteret af nyere litteratur - og sprogteoretiske studier. I en femte gruppe finder man den pædagogiske forskning.

Selv om det unægtelig er lykkedes BB at fremdrage noget karakteristisk for de forskellige nævnte forskere, må dog siges

- at nogle af forskerne kan indordnes i mere end én kategori.

Høirup har indgående beskæftiget sig med de logiske tankestrukturer hos Grundtvig. Han er altså også »strukturel« - ikke blot »historiskkomparativ«. - Flemming Lundgreen-Nielsens store disputats i to bind dækker faktisk alle tre kategorier. - Og hvis det at have skrevet om Grundtvig og romantikken er et af kriterierne på at høre til i tredie kategori, så burde både Scharling og Michelsen henregnes hertil og ikke til den første.

- en lang række forskere er overhovedet ikke inddraget, fx Aames, Albeck, Thodberg, Pontoppidan Thyssen o.a.

Selv om BB i note 39 tager et vist forbehold, så måtte man i betragtning af de nævnte vanskeligheder have foretrukket en kronolo- 
gisk ordnet oversigt med en kort karakteristik af de vigtigste værker fra de pågældende perioder.

Dernæst savnes en drøftelse af tidligere behandlinger af emnet »Skriftlighed og mundtlighed hos Grundtvig«. Først og fremmest savnes en henvisning til Gustav Albecks store artikel om »Det levende Ord«, trykt i tidsskriftet Sprog og Kultur bd. 18 (Aarhus 1951), siden optrykt i Modersmål-Selskabets årbog 1983. Af Vilhelm Nielsens behandlinger af emnet er kun én nævnt. - Henning Hфirups bog „Fra Døden til Livet« (1954) er anført i litteraturlisten. Dog kan det undre, at bogens udførlige redegørelse for »Ordets Liv og Ordets Død « (s. 66-88) ikke har givet BB anledning til henvisninger og kommentarer. Mest må man dog beklage, at BB ikke i højere grad har udnyttet den indsigt, der foreligger i Helge Toldbergs forfatterskab. På s. 229f savnes en henvisning til HTs første bog, »Grundtvig som filolog « (1946), hvor et helt kapitel omhandler Grundtvigs arbejde med ordsprog. Endvidere kunne man have forventet, at BB havde diskuteret HTs behandling af temaet mundtlighed-skriftlighed i disputatsen »Grundtvigs Symbolverden« (1950) kap. 7 og 8.

Lad dette være tilstrækkeligt mht. supplerende og kritiske bemærkninger. Tiden er nu inde til at formulere nogle sammenfattende, konkluderende bemærkninger. På trods af de anførte fejl og mangler må en sammenfattende og afbalanceret vurdering konkludere i en række positive iagttagelser.

BBs disputats er for det første en særdeles velskrevet bog, som det har været en fornøjelse at læse. Dernæst skal fremhæves som noget overordentligt fortjenstfuldt, at BB har haft mod og evne til at kaste sig ud i et studium af forholdet mellem skriftlighed og mundtlighed hos Grundtvig, en helt central problemstilling i hans pædagogiske tænkning.

I flere henseender er BBs disputats et interessant arbejde. Herunder må først og fremmest nævnes, at søgelyset rettes mod skoleskrifternes litterare og sproglige egenskaber. Tidligere var det skrifternes idéer, der stod i centrum, herunder idéernes historiske baggrund og samtidige kontekst. Under inspiration af nyere litteraturteori og sprogfilosofi har BB bidraget til at føre Grundtvig-forskningen videre, så sandt som enhver tidsepoke må tolke Grundtvig ud fra nye forudsætninger dvs. under hensyntagen til de idéer, der kommer frem i hver ny forskergeneration. 
Fremdeles noteres, at BB har bestræbt sig på at inddrage det væsentligste af den videnskabelige Grundtvig-litteratur, der kan siges at være relevant. At der i så henseende kan påvises enkelte mangler, rokker ikke ved denne generelle vurdering. Langt vigtigere er det, at BBs vurderinger af andre forskere og deres resultater er forsigtige, velbegrundede og vel værd at overveje.

I arbejdet med Grundtvigs tekster har BB ved sin fremdragelse af hovedsynspunkter evnet at give et godt indtryk af Grundtvigs indholdsrige tekster og undertiden meget koncentrerede tankeudvikling. I sammenhæng hermed bemærkes en ydmyghed over for opgaven. Hele vejen igennem fastholder BB en distance til teksterne og understreger deres gådefuldhed. Det er en holdning, der minder om den, der i sin tid kom til orde hos religionshistorikeren Vilhelm Grønbech, der skrev: „Grundtvig tager til i hemmelighedsfuldhed, jo nærmere man kommer ham ind på livet « (Kampen om Mennesket, København 1949, s. 142).

Det tjener BB til ære, at han i så mange henseender - og altså også på denne måde - er kommet Grundtvig »ind på livet«. 